\title{
Determinants and challenges in online shopping in Kerala
}

\author{
Haritha Paul, R. Krishna and K.N. Ushadevi
}

Received : 18.01.2019; Revised : 11.03.2019; Accepted : 23.03.2019

\begin{abstract}
Considering the promising future of on line marketing the study aimed to analyse the determinants and constraints of on line marketing. 120 students (who were engaging in online shopping) selected from two colleges (representing one professional and one traditional college) from Thrissur district consisting of 60 male and 60 female respondents were equally selected and primary survey was conducted through a structured interview schedule. The study highlighted that major factor of online shopping is convenience. Online marketers may pay more attention to free delivery, or free gift and do the best to build, enhance and maintain their good reputation. Delivery in time is an vital factor and important constraint, the proper delivery in time and nearest place it will create trust and image of the websites, therefore, advisable to concentrate on proper delivery services.
\end{abstract}

KEY WORDS : On line marketing, Determinants, Constraints online shopping behaviour

How to cite this paper: Paul, Haritha, Krishna, R. and Ushadevi, K.N. (2019). Determinants and challenges in online shopping in Kerala. Internat. J. Com. \& Bus. Manage, 12(1) : 23-27, DOI: 10.15740/HAS/IJCBM/12.1/23-27. Copyright@ 2019: Hind Agri-Horticultural Society.

\section{MEMBERS OF THE RESEARCH FORUM}

Correspondence to:

Haritha Paul, Department of Rural Marketing Management, College of Co-operation, Banking and Management, Kerala Agricultural University, Vellanikkara, Thrissur (Kerala) India

E-mail:1994hpk@gmail.com

\section{Authors' affiliations:}

R. Krishna, Christ College (Calicut University), Irinjalakkuda, Thrissur (Kerala) India E-mail: krishnanair44@gmail.com

$\overline{\text { K.N. Ushadevi, Department of Rural Marketing Management, Kerala }}$ Agricultural University, Vellanikkara, Thrissur (Kerala) India

E-mail: usha82.94@gmail.com 